\section{Copper-based alloy artefacts from the Témiscamingue fur trade post (Quebec, Canada)}

\author{
Jean-François Moreau, ${ }^{1}$ \\ Ron G.V. Hancock, ${ }^{2}$ Marc Côté ${ }^{3}$ \\ 'Laboratoire d'Archéologie et \\ Département des Sciences Humaines, \\ Université du Québec à Chicoutimi, \\ Chicoutimi; ${ }^{2}$ Department of Medical \\ Physics and Applied Radiation Sciences \\ and Department of Anthropology, \\ McMaster University Hamilton, Ontario; \\ ${ }^{3}$ Corporation Archéo-08, Évain, Quebec, \\ Canada
}

\begin{abstract}
One hundred and forty-four artefacts from the collection of copper-based alloy specimens excavated from the site of Fort Témiscamingue (Western Quebec, Canada; late $16^{\text {th }}$ to $18^{\text {th }}$ centuries) were submitted to instrumental neutron activation analysis. While some specimens were brassy copper (high copper and very low zinc content), others were brass (lower copper and high zinc content). The brass artefacts confirm the indication based on historical documents of the settling of Fort Témiscamingue in the 1720 since metal $\mathrm{Zn}$ began to be produced in Europe by the beginning of the $18^{\text {th }}$ century. The brassy copper artefacts could be containers made with $17^{\text {th }}$ century techniques but still in use when Fort Témiscamingue was erected, or they could indicate direct or indirect trade with the French during the $17^{\text {th }}$ century.
\end{abstract}

\section{Introduction}

The Fort-Témiscamingue-Obadjiwan Cana dian national historic site ( $\mathrm{ChGu}-2)$ is located in Duhamel County on the Québec shore of Témiscamingue Lake, five kilometres southeast of Ville-Marie (Rouyn-NorandaTémiscamingue County). The location is across from a point, on the Ontario side of the lake (Figure 1), where the Saint-Claude Mission (ChGu-1) stood from 1863 to 1887 , run by the Marie-Immaculée Oblates. An archaeological dig was conducted on the site in 1994 (Pollock, 1994).

As illustrated by its Algonquin name (Obadjewong, 8apaje8awan: straight; as the Fort-Témiscamingue-Obadjiwan Canadian national historic site is known to the Algonquin people today. The term, which has been written in various ways over the years, was already documented in $18^{\text {th }}$ century writings), Fort Témiscamingue and Mission Point form a bottleneck where anyone trying to get through by canoe is easily spotted. The location yields a magnificent view. In 1841, Father Charles Édouard Poiré mentioned that, on a clear day, one can see as far as 7 leagues to the west and 1 league to the east, the view being blocked on that side by Île du Collège et Baie des Pères point.

Taking a look at a regional map (Figure 1) one notes that the site is located midway between the head of the lake and the mouth of the Montréal River, which approximately bounds off the Ottawa River and Témiscamingue Lake. The site sits on a bench, on average about three metres above the current lake level. The terrace around the site is very steep. It was solidified by stonework, which protects the shore from the erosion that caused serious problems when the lake overwashed in the early $20^{\text {th }}$ century. The bench rises towards the interior for about one hundred metres, up to a second change in level, which slopes upwards and inland into a mound. Along the south shore, the site turns into a gentle downward slope to the gravelly beach along a large indented bay.

Across from the mission, where the lake bells out again, opens a large, perfectly oval bay, so harmonious a design, it reminds one of a balloon glass painstakingly shaped and rounded by the hand of time (Soulerin, 1884).

Besides the periodically attested Amerindian presence over the past six millennia, the place is renowned as the location where a trading post was established and successively run by various companies (Côté, 2006). The bestrecorded periods are those of the Northwest Company starting in 1795, and the Hudson Bay Company, which managed the post in 1821 . But traders from Montreal, led by Paul Guillet, had erected a first post under commission by the Governor of the Colony, Pierre de Rigaud de Cavagnal, Marquis de Vaudreuil.

The motives behind setting up a trading post at that precise location remain unknown. However, several factors relative to morphology and geography, along with the nature of the activities that were to be conducted there, can be put forward in as much as those same reasons likely motivated that same choice by their aboriginal predecessors.

The shores of the lake have different morphologies on the Ontario and Quebec sides. The Ontario shores are abrupt and austere. They are reminiscent of the Saguenay Fjord, as stated by the early missionaries. For example, Devil Point is a cliff that rises as high as 120 metres above the water, and dives $300 \mathrm{~m}$ below the surface. On the other hand, the Quebec shore is only slightly undulated and is indented by a series of narrow points and bays that are clearly more appealing to visitors arriving
Correspondence: Jean-François Moreau, Laboratoire d'archéologie et Département des Sciences Humaines, Université du Québec à Chicoutimi, 555 Boulevard Université Chicoutimi, Ouebec G7H 2B1, Canada.

Tel.Fax : + 1.418.545.5011

E-mail: jean-francois_moreau@uqac.ca

Key words: Québec, Abitibi-Témiscamingue, contact period, copper-based alloys.

Citation: Moreau J-F, Hancock RGV, Côté M, 2013. Copper-based alloy artefacts from the Témiscamingue fur trade post (Québec, Canada). In: RH Tykot (ed.), Proceedings of the $38^{\text {th }}$ International Symposium on Archaeometry - May $10^{\text {th }}-14^{\text {th }} 2010$, Tampa, Florida. Open Journal of Archaeometry 1:e27.

Presented at the $38^{\text {th }}$ International Symposium on Archaeometry - May $10^{\text {th }}-14^{\text {th }} 2010$, Tampa, Florida.

This work is licensed under a Creative Commons Attribution 3.0 License (by-nc 3.0).

(C) Copyright J-F. Moreau et al., 2013

Licensee PAGEPress, Italy

Open Journal of Archaeometry 2013; 1:e27

doi:10.4081/arc.2013.e27

on water. That is most likely why it was easier and less dangerous to settle on the east side of the lake.

All in all, it would seem that the FortTémiscamingue-Obadjiwan Canadian national historic site occupies a strategic position on the lakeshore. Moreover, when the a priori logistic advantages are added in the balance (drinking water, slope, drainage, protection against the elements), the point offers the principal characteristics sought by Amerindian hunter-gatherers, as well as the fur traders that followed in their footsteps.

\section{Materials and Methods}

The copper-based artefacts from Fort Témiscamingue were analysed by means of instrumental neutron activation analysis (INAA) at the $\mathrm{U}$ of $\mathrm{T}$ SLOWPOKE Reactor Facility. Samples of 10-20 mg were first irradiated serially for five minutes at a neutron flux of $5.0 \times 10^{11} \mathrm{n} . \mathrm{cm}^{-2} \cdot \mathrm{s}^{-1}$ and assayed for $5 \mathrm{~min}$ after a delay time of approximately thirty minutes using germanium detector-based gamma ray spectrometers for $\mathrm{Zn}, \mathrm{Cu}, \mathrm{Mn}$ and $\mathrm{In}$. Elemental concentrations were calculated using the comparator method. Larger samples were irradiated at suitably lower neutron fluxes so that a relatively consistent total amount of radioactivity was produced in each sample.

Medium and long half-life radioisotope pro- 
ducing elements were analysed by batch irradiating 10 to 20 samples per irradiation container for $16 \mathrm{~h}$ at $2.5 \times 10^{11} \mathrm{n} . \mathrm{cm}^{-2} \cdot \mathrm{s}^{-1}$. After 5 to 9 days, these samples were serially assayed for 500 to $1000 \mathrm{sec}$ looking for $\mathrm{Au}, \mathrm{Cu}, \mathrm{Cd}, \mathrm{As}, \mathrm{Sb}$, $\mathrm{Ag}, \mathrm{Zn}$ and $\mathrm{Na}$. A final counting was made after 9 to 18 days, at which time the samples were counted for 2000 to $8000 \mathrm{sec}$ to determine the concentrations of $\mathrm{Sn}, \mathrm{Se}, \mathrm{Hg}, \mathrm{Au}, \mathrm{As}, \mathrm{Sb}, \mathrm{Ag}, \mathrm{Ni}$, Sc, Fe, Zn and Co.

\section{Results and Discussion}

Overall, 144 artefacts from the Fort Témiscamingue were analyzed by means of this method. Except for a few cases of cast specimens (medallions, buttons, bracelets and lugs), these specimens are presumably remnants of containers (cauldrons, kettles). More specifically, these containers comprised a body made by hammering a sheet of copper-based alloy, the upper part of the body being generally folded on an iron rod. Two lugs were riveted on opposite sides of the body whether they were made by casting or folding of a small sheet of copper-based alloy on both sides of the containers (Moreau and Hancock, 1999). As reported in Table 1, 122 specimens are mainly fragments of sheets and the majority of them (110) are made of brass. As reported in Table 2 , among the 12 other sheet fragments, nine are made of $c a .100 \%$ of $\mathrm{Zn}$, two, presumably, of pewter (Sn between 66 and 73\%, with a calculated lead value of about $30 \%$ ) and one sheet of $94 \%$ Fe. As indicated in Table 3, the 110 fragments of Cu-based alloy exhibit traces of In, an indication of European origin as reported in previous studies (Hancock et al., 1991, 1999). These fragments include one brass specimen (bottom of Table 3 ) with a very low $\mathrm{Cu}$ content

Table 1. Summary of the artefacts from Fort Témiscamingue analysed with instrumental neutron activation analysis.

\begin{tabular}{llc}
\hline Fragment types & Composition & Fragiment no. \\
\multirow{2}{*}{ Non-composite fragments } & Very high Zn (ca. 100\%) & 9 \\
& Very high Sn (66-73\%) & 2 \\
& Very high Fe (98\%) & 1 \\
& Very high Cu (94-100\%), very low Zn (0.006-0.02\%) & 63 \\
& High Cu (84-94\%), low Zn (5-9\%) & 4 \\
& Low Cu (65-81\%), high Zn (18-33\%) & 42 \\
& Very low Cu (49\%), high Zn (28\%) & 1 \\
Composite fragments/wires & Sheets with rivets & 7 \\
& Rivets & 10 \\
& Wires & 5 \\
\hline Total & & 144
\end{tabular}

Zn, zinc; Sn, tin; Fe, iron; Cu, copper.

Table 2. Non copper-based alloy artefacts from Fort Témiscamingue.

\begin{tabular}{|c|c|c|c|c|c|c|c|c|c|c|c|c|c|c|}
\hline $\begin{array}{l}\text { Predominant } \\
\text { material }\end{array}$ & Fragment no. & Description & $\begin{array}{c}\mathrm{Mn} \\
(\mathrm{ppm})\end{array}$ & $\begin{array}{l}\text { In } \\
(\mathrm{ppm})\end{array}$ & $\begin{array}{c}\text { As } \\
(\mathrm{ppm})\end{array}$ & $\begin{array}{l}\mathrm{Cu} \\
(\%)\end{array}$ & $\begin{array}{c}\mathrm{Ag} \\
(\mathrm{ppm})\end{array}$ & $\begin{array}{c}\mathrm{Au} \\
(\mathrm{ppb})\end{array}$ & $\begin{array}{c}\mathrm{Co}_{0} \\
(\mathrm{ppm})\end{array}$ & $\begin{array}{l}\mathrm{Fe} \\
(\%)\end{array}$ & $\begin{array}{c}\mathrm{Ni} \\
(\mathrm{ppm})\end{array}$ & $\begin{array}{c}\mathrm{Sb} \\
(\mathrm{ppm})\end{array}$ & $\begin{array}{l}\mathrm{Sn} \\
(\%)\end{array}$ & $\begin{array}{l}\text { Zn } \\
(\%)\end{array}$ \\
\hline Zinc & $\begin{array}{l}14 \\
47 \\
40 \\
41 \\
45 \\
46 \\
48 \\
49 \\
44\end{array}$ & $\begin{array}{l}\text { Sheet with hole } \\
\text { Small fragment of sheet } \\
\text { Small fragment of sheet } \\
\text { Fragment of sheet } \\
\text { Fragment of sheet } \\
\text { Fragment of sheet } \\
\text { Small fragment of sheet } \\
\text { Small fragment of sheet } \\
\text { Big fragment of sheet }\end{array}$ & $\begin{array}{c}12 \\
11 \\
11 \\
11 \\
12 \\
8 \\
22 \\
7 \\
10\end{array}$ & $\begin{array}{c}40 \\
7.8 \\
6.2 \\
5.8 \\
5.5 \\
7.5 \\
6.1 \\
6.6 \\
6\end{array}$ & $\begin{array}{l}<7 \\
39 \\
29 \\
29 \\
32 \\
39 \\
30 \\
35 \\
25\end{array}$ & $\begin{array}{l}2.7 \\
0 \\
0 \\
0 \\
0 \\
0 \\
0 \\
0 \\
2\end{array}$ & $\begin{array}{l}<47 \\
<34 \\
<34 \\
<24 \\
<30 \\
<36 \\
<29 \\
<24 \\
<35\end{array}$ & $\begin{array}{l}<62 \\
<52 \\
<48 \\
<36 \\
<44 \\
<50 \\
<43 \\
<35 \\
<51\end{array}$ & $\begin{array}{l}<4.1 \\
<3.5 \\
<3.5 \\
<2.4 \\
<3 \\
<4 \\
<2.9 \\
<2.5 \\
<3.7\end{array}$ & $\begin{array}{l}<0.29 \\
<0.25 \\
<0.24 \\
<0.17 \\
<0.22 \\
<0.26 \\
<0.22 \\
<0.17 \\
<0.25\end{array}$ & $\begin{array}{l}<920 \\
<800 \\
<780 \\
<570 \\
<710 \\
<840 \\
<690 \\
<560 \\
<810\end{array}$ & $\begin{array}{c}21 \\
3.9 \\
3.6 \\
2.9 \\
4.1 \\
4.1 \\
3.7 \\
4 \\
2.7\end{array}$ & $\begin{array}{l}<0.08 \\
<0.07 \\
<0.07 \\
<0.04 \\
<0.06 \\
<0.08 \\
<0.05 \\
<0.04 \\
<0.08\end{array}$ & $\begin{array}{l}106 \\
100 \\
99 \\
99 \\
99 \\
99 \\
99 \\
99 \\
97\end{array}$ \\
\hline Pewter & $\begin{array}{c}22 \\
127\end{array}$ & $\begin{array}{l}\text { Rectangular sheet } \\
\text { Small irregular fragment } \\
\text { of sheet with hole }\end{array}$ & $\begin{array}{c}67 \\
<3.2\end{array}$ & $\begin{array}{l}17 \\
19\end{array}$ & $\begin{array}{l}1850 \\
1600\end{array}$ & $\begin{array}{l}5.4 \\
5.4\end{array}$ & $\begin{array}{l}<60 \\
<146\end{array}$ & $\begin{array}{l}<1600 \\
<3700\end{array}$ & $\begin{array}{l}<22 \\
<67\end{array}$ & $\begin{array}{l}<1.3 \\
<1.8\end{array}$ & $\begin{array}{l}<180 \\
<2600\end{array}$ & $\begin{array}{c}3700 \\
50700\end{array}$ & $\begin{array}{l}73 \\
67\end{array}$ & $\begin{array}{l}<0.06 \\
<0.22\end{array}$ \\
\hline Iron & 30 & Small fragment of sheet & 770 & $<0.3$ & $<3.1$ & 0 & $<11$ & 360 & 6.9 & 98.5 & $<220$ & 4 & $<0.06$ & 0.02 \\
\hline
\end{tabular}

Mn, manganese; In, indium; As, arsenic; Cu, copper; Ag, silver; Au, gold; Co, cobalt; Fe, iron; Ni, nickel; Sb, antimony; Sn, tin; Zn, zinc.

Table 3. Copper-based sheet fragments from Fort Témiscamingue.

\begin{tabular}{|c|c|c|c|c|c|c|c|c|c|c|c|}
\hline Fragments type & $\begin{array}{l}\text { Description } \\
(\%)\end{array}$ & $\begin{array}{c}\mathrm{Cu} \\
(\mathrm{ppm})\end{array}$ & $\begin{array}{c}\text { In } \\
(\mathrm{ppm})\end{array}$ & $\begin{array}{c}\mathrm{Ag} \\
(\mathrm{ppm})\end{array}$ & $\begin{array}{c}\text { Au } \\
(\mathrm{ppm})\end{array}$ & $\begin{array}{c}\mathrm{Fe} \\
(\mathrm{ppm})\end{array}$ & $\begin{array}{c}\text { As } \\
(\mathrm{ppm})\end{array}$ & $\begin{array}{l}\text { Sb } \\
(\%)\end{array}$ & $\begin{array}{l}\text { Sn } \\
(\%)\end{array}$ & $\mathrm{Zn}$ & Period \\
\hline $\begin{array}{l}\text { Brassy } \mathrm{Cu} \\
\quad \mathrm{Cu}: 94-99.9 \% \\
\text { Zn: } 0.01-4 \%\end{array}$ & $\begin{array}{l}\text { Fragment no. } \\
\text { Mean } \\
\text { SD }\end{array}$ & $\begin{array}{c}98 \\
0.90\end{array}$ & $\begin{array}{l}1.07 \\
0.93\end{array}$ & $\begin{array}{l}890 \\
350\end{array}$ & $\begin{array}{l}3.8 \\
4.7\end{array}$ & $\begin{array}{c}63 \\
690 \\
250\end{array}$ & $\begin{array}{l}4340 \\
2240\end{array}$ & $\begin{array}{l}250 \\
220\end{array}$ & $\begin{array}{l}0.18 \\
0.38\end{array}$ & $\begin{array}{l}0.03 \\
0.08\end{array}$ & $\begin{array}{c}\text { French } \\
\text { Regime } \\
1600-1750\end{array}$ \\
\hline $\begin{array}{c}\text { Brass high Cu } \\
\text { Cu: } 84-93 \% \\
\text { Zn: } 5-9 \%\end{array}$ & $\begin{array}{l}\text { Fragment no. } \\
\text { Mean } \\
\text { SD }\end{array}$ & $\begin{array}{l}92 \\
6.3\end{array}$ & $\begin{array}{l}0.9 \\
0.2\end{array}$ & $\begin{array}{l}960 \\
150\end{array}$ & $\begin{array}{l}4.3 \\
2.7\end{array}$ & $\begin{array}{c}4 \\
1470 \\
1060\end{array}$ & $\begin{array}{l}5630 \\
4150\end{array}$ & $\begin{array}{l}470 \\
360\end{array}$ & $\begin{array}{l}3.3 \\
6.4\end{array}$ & $\begin{array}{l}6.2 \\
1.6\end{array}$ & $\begin{array}{c}\text { English } \\
\text { Regime } \\
1750-1900\end{array}$ \\
\hline $\begin{array}{r}\text { Brass low } \mathrm{Cu} \\
\text { Cu: } 65-81 \% \\
\text { Zn: } 18-32 \%\end{array}$ & $\begin{array}{l}\text { Fragment no. } \\
\text { Mean } \\
\text { SD }\end{array}$ & $\begin{array}{l}71 \\
3.4\end{array}$ & $\begin{array}{l}8.7 \\
8.2\end{array}$ & $\begin{array}{l}660 \\
480\end{array}$ & $\begin{array}{l}6.6 \\
7.4\end{array}$ & $\begin{array}{c}42 \\
1660 \\
680\end{array}$ & $\begin{array}{l}1780 \\
2230\end{array}$ & $\begin{array}{l}140 \\
150\end{array}$ & $\begin{array}{l}0.1 \\
0.2\end{array}$ & $\begin{array}{l}28 \\
3.4\end{array}$ & $\begin{array}{c}\text { English } \\
\text { Regime } \\
1750-1900\end{array}$ \\
\hline $\begin{array}{l}\text { Brass very low } \mathrm{Cu} \\
\text { Cu: } 49 \% \\
\text { Zn: } 28 \% \\
\end{array}$ & $\begin{array}{l}\text { Fragment no. } \\
\text { Mean } \\
\text { SD }\end{array}$ & $\begin{array}{c}49 \\
0\end{array}$ & $\begin{array}{c}3.5 \\
0\end{array}$ & $\begin{array}{c}787 \\
0\end{array}$ & $\begin{array}{c}4.6 \\
0\end{array}$ & $\begin{array}{c}1 \\
1500 \\
0\end{array}$ & $\begin{array}{c}1400 \\
0\end{array}$ & $\begin{array}{c}115 \\
0\end{array}$ & $\begin{array}{c}0.019 \\
0\end{array}$ & $\begin{array}{c}28 \\
0\end{array}$ & $\begin{array}{c}\text { English } \\
\text { Regime } \\
1750-1900\end{array}$ \\
\hline
\end{tabular}

$\mathrm{Cu}$, copper; In, indium; Ag, silver; Au, gold; Fe, iron; As, arsenic; Sb, antimony; Sn, tin; Zn, zinc; SD, standard deviation. 
of $49 \% \mathrm{Cu}(28 \% \mathrm{Zn})$. The remaining 109 fragments of sheet made of Cu-based alloy split into three groups (Table 3). The general morphology of these 110 specimens is reported in Table 4. Excluding few artefacts resulting from casting activities, most of these artefacts are fragments of sheets, presumably most of them being parts of containers (cauldrons, kettles).

Sixty-three of them may be assigned to the brassy copper-based artefacts category, since their mean $\mathrm{Cu}$ is on the order of well over $95 \%$ with maximum values of $\mathrm{Zn}$ around $4 \%$. Fortytwo sheet fragments are yellow brasses with a mean $\mathrm{Cu}$ value of about $71 \%$ for $\mathrm{Cu}$ (range of observed values between 65 and $81 \%$ ) and a mean $\mathrm{Zn}$ value of $28 \%$ (range=18-32\%). Relative to their Zn content, four specimens of reddish brass would fall between the brassy copper and yellow brasses. Hence, two tight clusters of sheets are noted in the Cu-based artefacts of Fort Témiscamingue. Table 5 reports the elemental composition of i) several composite sheets (generally sheets with rivets) not excluded from the 110 fragments of sheets reported above; ii) several of the rivets of these composite sheets; and iii) the five wires that have been analysed by INAA. The seven sheets of the composite fragments exhibit high $\mathrm{Cu}$ and very low $\mathrm{Zn}$; hence, they would be akin to the brassy sheets. The middle part of Table 5 describes the 10 rivets attached to the composite fragments. Their very high $\mathrm{Cu}$ values are akin to the High $\mathrm{Cu}$ rivet category reported in Moreau and Hancock (1996). It
Table 4. Morphology of the sheet fragments from Fort Témsicamingue.

\begin{tabular}{|c|c|c|c|c|}
\hline \multirow[t]{2}{*}{ Morphological categories } & \multicolumn{2}{|c|}{ Brassy } & \multicolumn{2}{|c|}{ Brass } \\
\hline & $\mathrm{Cu}$ & $\begin{array}{c}\text { High } \\
\mathrm{Cu}\end{array}$ & $\begin{array}{c}\text { Low } \\
\mathrm{Cu}\end{array}$ & $\begin{array}{l}\text { Very } \\
\text { low } \mathrm{Cu}\end{array}$ \\
\hline (Long, very long) (thin) strip of sheet & 5 & & 6 & \\
\hline (Rectangular) sheet with holes & 4 & 1 & 6 & \\
\hline Sliver (small fragment) of sheet & 7 & 7 & & \\
\hline Large sheet $(20$ x $30 \mathrm{~cm})$ & 2 & & & \\
\hline Fragment of (thick) sheet & 7 & & & \\
\hline Sheet (fragment of) & 1 & 3 & & \\
\hline (Small) rectangular (square, quadrilateral) sheet & 6 & 1 & 4 & 1 \\
\hline Sub-rectangular sheet & 3 & 1 & & \\
\hline Rhomboidal sheet & 1 & & & \\
\hline Trapezoidal sheet & 2 & 1 & & \\
\hline Triangular (fragment) of sheet & 3 & 1 & 5 & \\
\hline Crescent shape sheet & & 1 & & \\
\hline Irregular fragment of (thick) sheet & 5 & & & \\
\hline Folded strip/fragment of sheet & 7 & 2 & & \\
\hline Narrow bent strip (of sheet) & 4 & 1 & & \\
\hline (Wrinkled) lug & 2 & 1 & & \\
\hline Rim part of a kettle & 1 & & & \\
\hline Tubular fragment & & 1 & & \\
\hline Fragment of a brass box & 1 & & & \\
\hline Thick corroded needle like object & 2 & & & \\
\hline Thick V shaped piece & & 1 & & \\
\hline Button & & 1 & & \\
\hline Bracelet & & 1 & & \\
\hline Part of rosary medalion & & 1 & & \\
\hline$(80$ & 63 & 4 & 42 & 1 \\
\hline
\end{tabular}

Table 5. Composite (sheets and rivets) fragments, rivets and wires from Fort Témiscamingue.

\begin{tabular}{|c|c|c|c|c|c|c|c|c|c|c|}
\hline Fragment no. & Description & $\begin{array}{c}\mathrm{Cu} \\
(\%)\end{array}$ & $\begin{array}{c}\text { In } \\
(\mathrm{ppm})\end{array}$ & $\begin{array}{c}\mathrm{Ag} \\
(\mathrm{ppm})\end{array}$ & $\begin{array}{c}\mathrm{Au} \\
(\mathrm{ppm})\end{array}$ & $\begin{array}{c}\mathrm{Fe} \\
(\mathrm{ppm})\end{array}$ & $\begin{array}{c}\text { As } \\
(\mathrm{ppm})\end{array}$ & $\begin{array}{c}\text { Sb } \\
(\mathrm{ppm})\end{array}$ & $\begin{array}{l}\text { Sn } \\
(\%)\end{array}$ & $\begin{array}{l}\mathrm{Zn} \\
(\%)\end{array}$ \\
\hline \multicolumn{11}{|c|}{ Composite fragments } \\
\hline 144 & Cast lug on 140 & 93 & 4.8 & 1100 & 8.9 & $<2000$ & 5620 & 589 & 1.76 & 4.1 \\
\hline 86 & Large fragment of sheet with three holes and one rivet & 97 & $<0.8$ & 820 & 9.8 & $<900$ & 4170 & 458 & $<0.02$ & $<0.01$ \\
\hline 140 & Large L shaped sheet with lug and three rivets & 98 & $<0.9$ & 930 & 1.5 & $<900$ & 4130 & 143 & $<0.02$ & $<0.006$ \\
\hline 121 & Long irregular sheet with four rivets & 98 & $<0.8$ & 1050 & 1.0 & $<1000$ & 4350 & 153 & $<0.02$ & $<0.006$ \\
\hline 58 & Front sheet of artifact of two sheets and rivet & 98 & 7.8 & 980 & 21.4 & $<2400$ & 1540 & 1620 & $<0.12$ & $<0.069$ \\
\hline 59 & Back sheet of artifact of two sheets and rivet & 98 & 8.3 & 930 & 20.6 & $<1700$ & 1190 & 1700 & 0.25 & 0.075 \\
\hline 90 & Crescent shape with hole and rivet & 99 & $<0.8$ & 1420 & 1.3 & $<940$ & 4620 & 192 & $<0.04$ & $<0.005$ \\
\hline \multicolumn{11}{|l|}{ Rivets } \\
\hline 141 & Right hand rivet of 140 & 94 & $<1.4$ & 640 & 2.5 & $<1000$ & 4430 & 178 & $<0.09$ & 3.4 \\
\hline 143 & central rivet for handle of 140 & 94 & 4.1 & 950 & 7.7 & 3780 & 5480 & 514 & 1.31 & 3.8 \\
\hline 142 & Left hand rivet of 140 & 96 & $<0.9$ & 810 & 2.6 & $<1300$ & 4410 & 205 & $<0.05$ & 3.3 \\
\hline 145 & Second rivet of 121 & 96 & $<1.2$ & 860 & 0.7 & $<1600$ & 4100 & 130 & $<0.07$ & 0.11 \\
\hline 87 & Rivet from 86 & 97 & 5.1 & 1030 & $<0.3$ & $<1200$ & 4170 & 148 & $<0.12$ & 0.065 \\
\hline 122 & Leftmost (first) rivet of 121 & 98 & $<0.7$ & 1230 & 1.1 & $<1100$ & 4850 & 183 & $<0.02$ & $<0.007$ \\
\hline 123 & Third rivet of 121 & 98 & $<0.7$ & 780 & 0.7 & $<600$ & 4460 & 115 & $<0.05$ & $<0.009$ \\
\hline 146 & Fourth rivet of 121 & 98 & $<1.4$ & 1060 & $<0.3$ & 2900 & 4820 & 160 & $<0.13$ & 0.069 \\
\hline 60 & Rivet of artifact of two sheets and rivet & 98 & 7.3 & 930 & 20.4 & $<910$ & 1390 & 1680 & $<0.04$ & 0.05 \\
\hline 91 & Rivet from 90 & 99 & $<1.1$ & 1060 & 1.9 & $<3000$ & 4200 & 161 & $<0.20$ & $<0.02$ \\
\hline \multicolumn{11}{|l|}{ Wires } \\
\hline 64 & Thin wire & 70 & $<0.7$ & $<19$ & 0.2 & 17100 & $<8$ & 3.7 & $<0.04$ & 27 \\
\hline 65 & Thin wire & 99 & $<0.7$ & 21 & 0.2 & $<340$ & $<15$ & 0.4 & $<0.02$ & 0.045 \\
\hline 70 & Thick wire & 99 & $<0.8$ & 11 & 0.05 & $<180$ & $<2.5$ & $<0.1$ & $<0.01$ & 0.012 \\
\hline 55 & Thick wire & 99 & $<1$ & 11 & 0.05 & $<150$ & $<2.8$ & 0.3 & $<0.01$ & 0.011 \\
\hline 37 & Thick wire & 99 & $<0.7$ & 50.1 & 1 & $<660$ & $<10$ & 2.8 & $<0.04$ & $<0.004$ \\
\hline
\end{tabular}

Cu, copper; In, indium; Ag, silver; Au, gold; Fe, iron; As, arsenic; Sb, antimony; Sn, tin; Zn, zinc. 


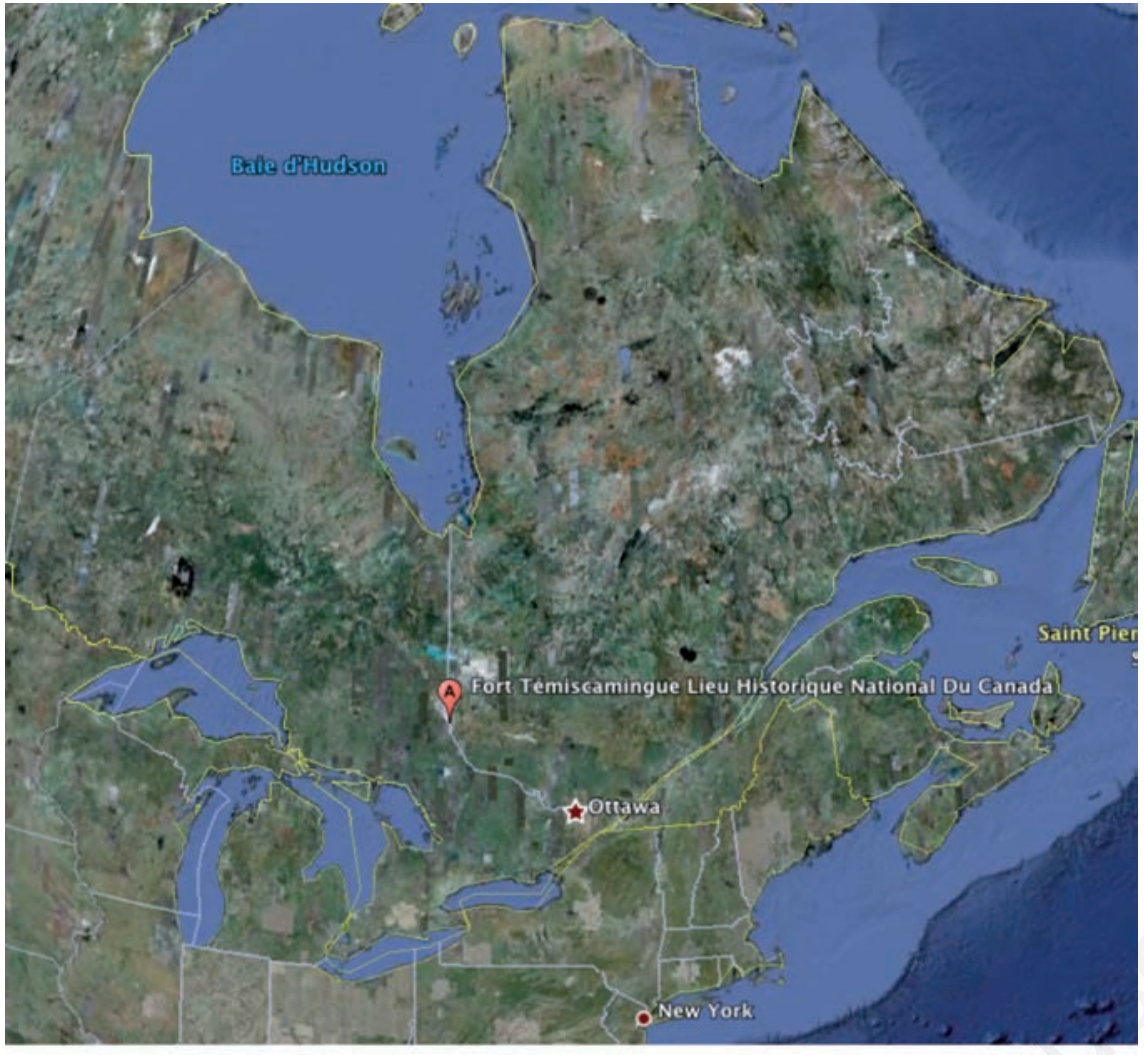

Figure 1. Location of Fort Témiscamingue.

should be enhanced that, as reported in this publication, this High Cu category far outnumbers the Low $\mathrm{Cu}$ (brass) rivets (33 against 7 specimens). The third part of Table 5 reports the elemental composition of five wires, all but one of very high $\mathrm{Cu}$ value, akin to the rivets reported above. Hence these wires could have been used for riveting. One wire exhibit a value of $70 \%$ of $\mathrm{Cu}$, akin to the few low $\mathrm{Cu}$ rivets reported in Moreau and Hancock (1996).

\section{Conclusions}

In as much as $\mathrm{Zn}$ content may be considered as time sensitive with increasing importance of $\mathrm{Zn}$ between the late $16^{\text {th }}$ and the $18^{\text {th }}$ century (Moreau and Hancock, 1996; Pollard, 2008), the brassy copper sheets could be early material of the French Regime; in fact these sheets may represent material that could predate the installation of Fort Témiscamingue; in short they could represent fur trading activities at its onset in the first half of the $17^{\text {th }}$ century.

The brass artefacts would represent occupation of the Fort Témiscamingue itself beginning by the 1720 . The nine sheets of $c a .100 \%$ Zn would also sustain such late occupation since the inception of techniques producing $\mathrm{Zn}$ metal date at the earliest in Europe to the 1740 (Richards, 2010).

In summary, two very tight and contrasted clusters of brassy copper and yellow brass reported above could be the result of intensive trading activities in the early $17^{\text {th }}$ century and during the late French and the English regimes (1720 onward) while these activities may have been of limited importance at the closing of the French regime (1675-1725). However, the possibility cannot be ignored that several and maybe all of the brassy copper fragments were $17^{\text {th }}$-century containers that were still in use in the $18^{\text {th }}$ century and, would thus be contemporaneous with the $18^{\text {th }}$ century brass artefacts not by their fabrication but by their utilization. Such observation at Fort Témiscamingue is also noted elsewhere: hence, Moreau and Hancock (2011) report that at Brador there also seems to be a noticeably less intense occupation between an early occupation during the first half of the $17^{\text {th }}$ century and a later (post-1704) occupation. Thus, far from the colonizing areas between Québec and Montréal, on the North shore of the Saint-Lawrence, the western (Témiscamingue) as well as the eastern (Brador) areas of New France exhibit a similar historical trajectory, as long as the elemental compositions of Cu-based alloy artefacts are concerned. On a technical side, compaired to the sheets making up the cauldrons, riveting seems to be done much more often with high-Cu objects as illustrated by the rivets themselves and by the several wires included in the sample of artefacts from the Témiscamingue trading fort.

\section{References}

Côté M, 2006. [L'occupation amérindienne au Témiscamingue: l'exemple du Lieu Historique national du canada de FortTémiscamingue/Obedjiwan]. [Article in French]. Rech Amerindien Que 36:7-22.

Hancock RGV, Farquhar RM, Pavlish LA, Salloum R, Fox WA, Wilson GC, 1999. North American native copper and European trade copper analyses. In: E. Pernicka, G.A. Wagner (eds.) Archaeometry-90. Birkhaüser Verlag, Boston, pp 173-82.

Hancock RGV, Pavlish LA, Farquhar RM, Salloum R, Fox WA, Wilson GC, 1991. Distinguishing European trade copper and North-Eastern North America native copper. Archaeometry 33:69-86.

Moreau J-F, Hancock RGV, 1996. Faces of European copper alloy cauldrons from Québec and Ontario 'contact' sites. In: S.M.M. Young, A.M. Pollard, P. Budd, R.A. Ixer (ed.) Metals in antiquity. Archaeopress, Oxford, pp 326-40.

Moreau J-F, Hancock RGV, 1999. [L'anatomie d'un chaudron]. In: J.-F. Moreau (ed.) [L'Archéologie sous la loupe. Contributions à l'archéométrie]. [Book in French]. Recherches amérindiennes au Québec ed., Montréal, pp. 73-86.

Moreau J-F, Hancock RGV, 2011. Copper-based kettles from Brador: a contribution to the study of eastern settlements of New France on the northern shore of the estuary of the Saint-Lawrence (Quebec, Canada). In: Proceedings of the 37 th International Symposium on Archaeometry, 13th-16th May 2008, Siena, Italy, pp 611-6. Springer.

Pollard AM, Heron C, 2008. Archaeological chemistry. RSC Publishing, Cambridge.

Pollock J, 1994. Final report archaeological test excavations site ChGu-1, Oblate mission (mission Saint-Claude) Lake Temiskaming, Ontario. Report prepared for Temiscaming Abitibi Heritage Association, Haileybury.

Richards AW, 2010. Zinc processing. In: Encyclopaedia Britannica, ultimate reference suite. Encyclopaedia Britannica ed., Chicago, IL, USA.

Soulerin A, 1884. [Le père Laverlochère: missionnaire Oblat de Marie-Immaculée: apôtre de la Baie d'Hudson]. [Book in French]. Delhomme et Briguet, Paris. 